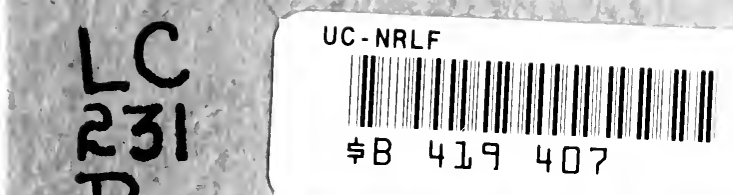



a

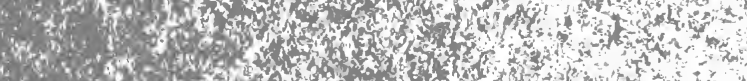

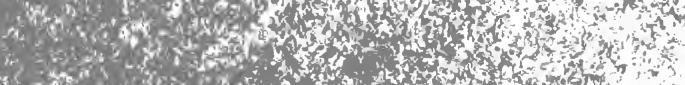

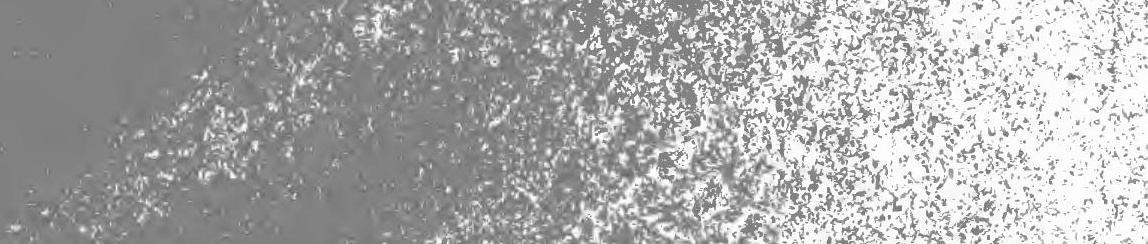

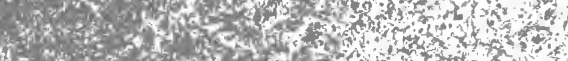

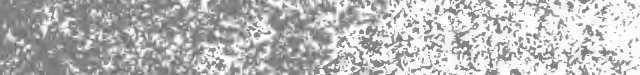

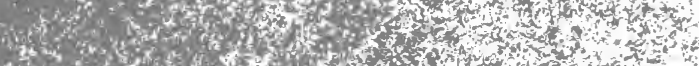

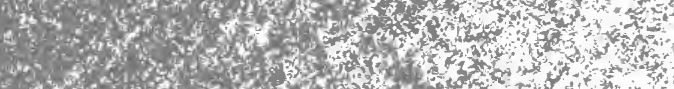

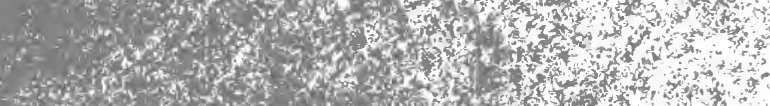

A

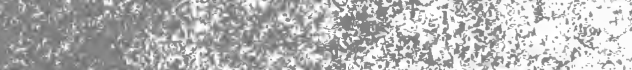

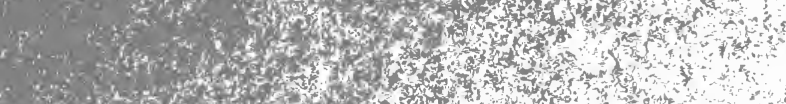

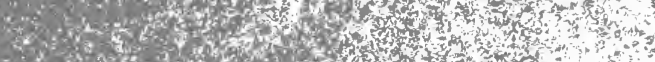

S.

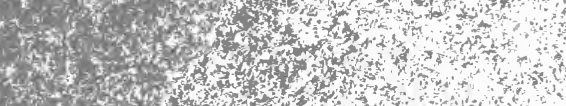

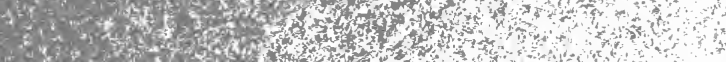

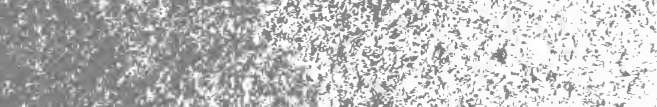

S

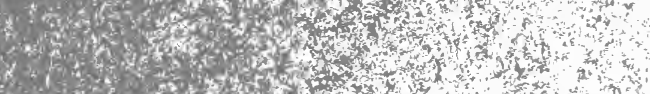

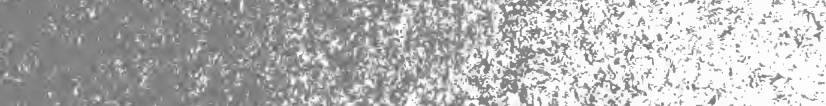

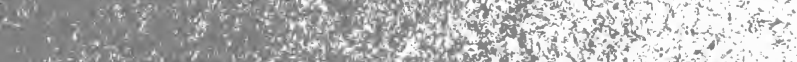

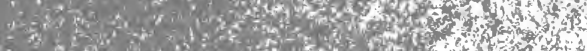

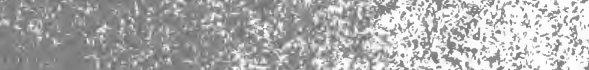

(2)

(3)

7.

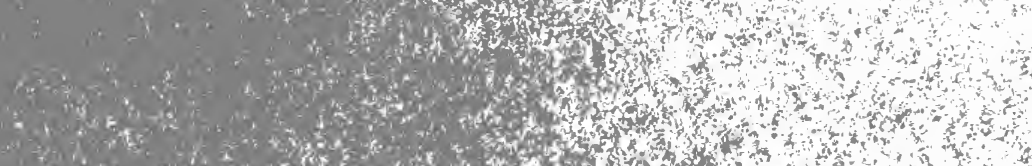

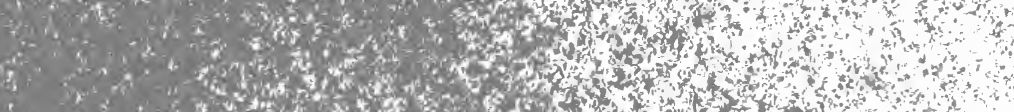

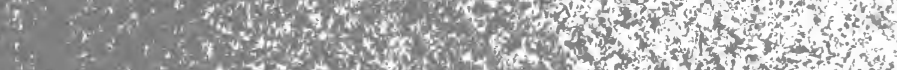

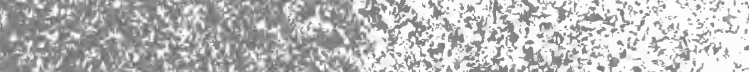

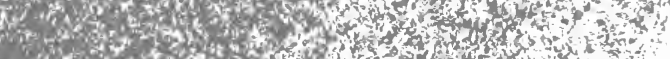

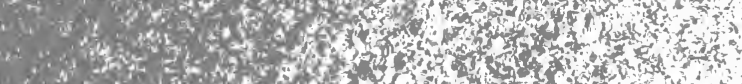

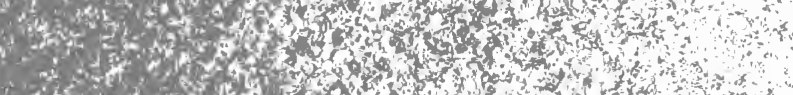

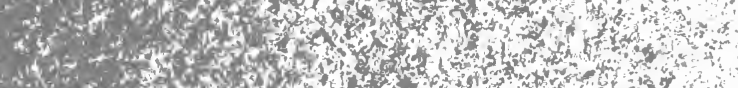

f.

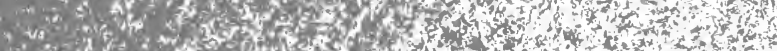

2. 25 .

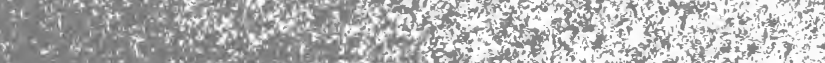




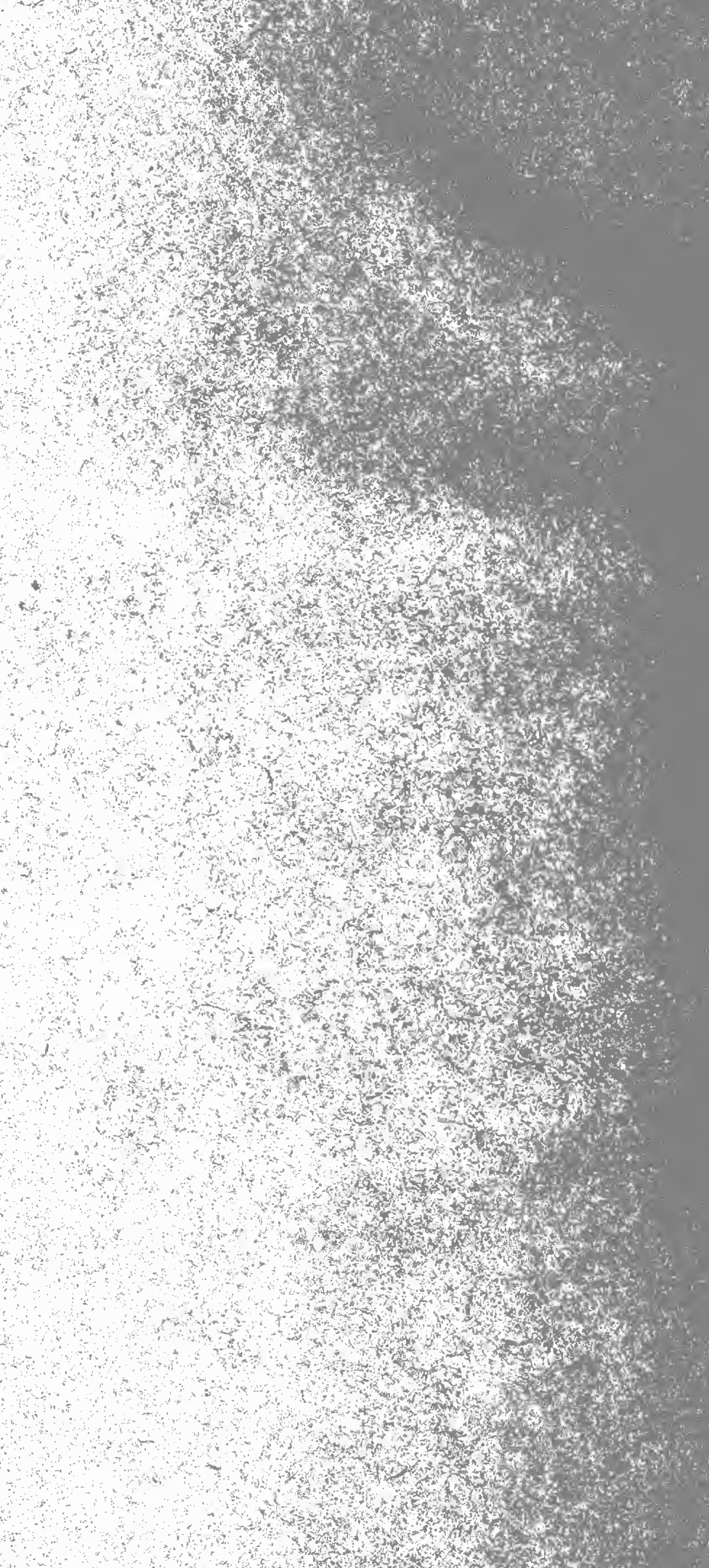




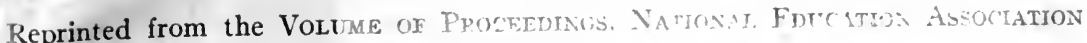

\section{THE PUBLIC LIBRARY, THE PUBLIC SCHOOL, AND THE SOCIAL CENTER MOVEMENT}

ARTHUR E. BOSTWICK, LIBRARIAN, PUBLIC LIBRARY, ST. LOUIS, MO.

The center "of a geometrical figure is important, not for its size and content, but for its position-not for what it is in itself, but for its relations to the other elements of the figure. And words used with derived meanings are used best when their original significations are kept in mind. The business center of a city does not contain all of that city's commercial activity; when we speak of the church as a religious center, we do not mean that there is to be no religious activity in the home or in other walks of life; as for the center of population of a large and populous country, it may be out in the prairie where neither man nor his dwellings are to be seen. All these centers are what they are because of certain relationships. It is so with a social center. But social relationships cover a wide field. The relationships of business, of religion, even of mere coexistence, are all social. May we have a center for so wide a range of activities? Eren the narrower relations of business or of religion tend to form subsidiary groups and to multiply subsidiary centers. In a large city we may have not only a general business center but centers of the real estate business, of the hardware or textile trades, and so on. Our religious affiliations condense into denominational centers.

In the district of a large city where newly arrived foreign immigrants gather, you will be shown the group of blocks where the Poles or the Hungarians have segregated themselves from the rest, and even within these, the houses where dwell families from a particular province or even from one definite city or village. Man is social, but he is socially clannish, and the broadest is not so much he who refuses to recognize these clan or caste relationships as he who enters into the largest number of them-he who keeps in touch with his childhood home, has a wide acquaintance among those of his own religious faith and of his chosen business or profession, keeps up his old college friendships, is interested in collecting coins or paintings and knows all the other collectors, is active in civic and charitable societies, takes an interest in education and educators, and so on. The social democracy that should succeed in abolishing all these groups or leveling them-that should recognize no relationships but the broader ones that underly all human effort and feeling-the touches of nature that make the whole world kin-would be barren indeed.

We cannot spare these fundamentals; we could not get rid of them if we would; but civilization advances by building upon them, and to do away with these additions would be like destroying a city to get at its foundations, in the vain hope of securing some wide-reaching result in economics or æsthetics. Occupying a foremost place among these groupings is the large division embracing our educational activities. And these are social 
not only in the broad sense, but also in the narrower. The intercourse of student with student in the school and even of reader with reader in the library, especially in such departments as the children's room, is so obviously that of society that we need dwell on it no further.

This intercourse, while a necessary incident of education in the mass, $\checkmark$ is only an incident. It is sufficiently obtrusive, however, to make it evident that any use of school or library building for social purposes is fit and proper. There is absolutely nothing new nor strange about such. use. In places that cannot afford separate buildings for these purposes, the same edifice has often served for church, schoolhouse, public library, and as assembly room for political meetings, amateur theatricals, and juvenile debating societies. The propriety of all this has never been questioned and it is difficult to see why it should not be as proper in a town of 500,000 inhabitants as in one of 500. The incidence of the cost is a matter of detail. Why should such purely social use of these educational buildings-always common in small towns-have been allowed to fall into abeyance in the larger ones? It is hard to say; but with the recent great improvements in construction, the building of schools and libraries that are models of beauty, comfort, and convenience, there has arisen a not unnatural feeling in the public that all this public property should be put to fuller use. Why should children be forced to dance on the street or in some place of sordid association when comfortable and convenient halls in library or school are closed and unoccupied? Why should the local debating club, the mothers' meeting-nay, why should the political ward meeting be barred out? Side by side with this trend of public opinion there has been an awakening realization on the part of many connected with these institutions that they themselves might benefit by such extended use.

Probably this realization has come earlier and more fully to the library, because its educational function is directed so much more upon adults. The library is coming to be our great continuation school-an institution of learning with an infinity of purely optional courses. It may open its doors to any form of adult social activity.

There are forms of activity proper to a social center that require special apparatus or equipment. These may be furnished in a building erected for the purpose, as are the Chicago fieldhouses. Here we have swimmingpools, gymnasiums for men and for women, and all the rest of it. A branch library is included and some would house the school also under the same roof. We may have to wait long for the general adoption of such a composite social center. Our immediate problem is to supply an immediate need by using means directly at our disposal. And it is remarkable how many kinds of neighborhood activity may take place in a room unprovided with any special equipment. A brief glance over our own records for only a few months past enables me to classify them roughly as athletic or out- 
door, purely social, educational, debating, political, labor, musical, religious, charitable or civic, and expository, besides many that defy or elude classification.

The athletic or outdoor organizations include the various turning or gymnastic clubs and the Boy and Girl Scouts; the social organizations embrace dancing-classes, "welfare" associations, alumni and graduate clubs of schools and colleges, and dramatic clubs; the educational, which are very numerous, reading circles, literary clubs galore, free classes in chemistry, French, psychology, philosophy, etc., and all such organizations as the Jewish Culture Club, the Young People's Ethical Society, the Longan Parliamentary Class, and the Industrial and Business Women's Educational leagues. Religious bodies are parish meetings, committees of mission boards, and such organizations as the Theosophical Society; charitable or civic activities include the National Conference of Day Nurseries, the Central Council of Civic Agencies, the W.C.T.U., playground rehearsals for the Child Welfare Exhibit, and the Business Men's Association, and the Advertising Men's League; musical organizations embrace St. Paul's Musical Assembly, the Tuesday Choral Club, etc. Among exhibitions are local affairs such as wildflower shows, an exhibit of birdhouses, collections from the Educational Museum, the Civic League's Municipal Exhibit, selected screens from the Child Welfare Exhibit, and the prize-winners from the St. Louis Art Exhibit held in the art room of our central library. Then we have the Queen Hedwig Branch, the Clay School Picnic Association, the Aero Club, the Lithuanian Club, the Philotechne Club, the Fathers' Club, and the United Spanish War Veterans.

I trust you will not call upon me to explain the objects of some of these, as such a demand might cause me embarrassment-not because their aims are unworthy, but because these are skillfully obscured by their names. If anyone believes that there is a limit to the capacity of the human race for forming groups and subgroups on a moment's notice, for any reason or for no reason at all, I would refer him to our assembly room and clubroom records; and he would find, I think, that these are typical of every large library offering the use of such rooms somewhat freely.

It will be noted that the library takes no part in organizing or operating any of these activities; it does not have to do so.

The successful leader is he who repairs to a hill and raises his standard, knowing that at sight of it followers will flock around him. When you drop a tiny crystal into a solution, the atoms all rush to it naturally: there is no effort or compulsion except that of the aptitudes that their Creator has implanted in them. So it is with all centers, business or religious or social. No one instituted a campaign to locate the business center of a 'city at precisely such a square or corner. Things aggregate, and the point 
to which they tend is their cfater; they make it, it does not make them. The leader on a hill is a leader because he has followers; without them he would be but a lone warrior. The school or the library that says proudly to itself, "Go to; I will be a social center," may find itself in the same lonely position. It can offer an opportunity: that is all. It can offer houseroom to clubs, organizations, and groups of all kinds, whether permanent or temporary, large or small, but its usefulness as a social center depends largely on the existence of these and on their desire for a meetingplace. We have in St. Louis six branch libraries with assembly rooms and clubrooms - in all a dozen or so. I have before me the calendar for a single week and I find 55 engagements, running from 24 at one branch down thru $\mathrm{I} 3,8,6$, and 3 to one. If $\mathrm{I}$ had before me only the largest number I should conclude that branch libraries as social centers were a howling success; if only the smallest, I should say that they were dismal failures. Why the difference? For the same reason that the leader who displays his standard may or may not be surrounded with eager "flocking" followers. There may be no one within earshot, or they may have no stomach for the war, or they may not be interested in the cause that he represents. Or again, he may not shout loud or persuasively enough, or his standard may not be attractive enough in form or color, or mounted on a sufficiently high staff.

I have said that all we can offer is opportunity; to change our figure, we can furnish the drinking-fountain - thirst must bring the horse to it. But we must not forget that we offer our opportunity in vain unless we are sure that everyone who might grasp it realizes our offer and what it means.

Here is the chance for personal endeavor. If the young people in a neighborhood continue to hold their social meetings over a saloo when the branch library or the school is perfectly willing to offer its assembly room, it is pretty certain that they do not understand that offer, or that they mistrust its sincerity, or that there is something wrong that might be remedied by personal effort. In the one of our branches that is most used by organizations there is this personal touch. But I should hesitate to say that the others do not have it too. There are plenty of organizations near this busiest library and there are no other good places for them to meet. In the neighborhood of some other branches there are other meeting-places, and elsewhere, perhaps, the social instinct is not so strong, or at any rate the effort to organize is lacking. Should the librarian step out and attempt to stimulate this social instinct and to guide this organizing effort? There is room for difference of opinion here.

Personally I think that he should not do it directly and officially as a librarian. He may do it quietly and unobtrusively like any other private citizen, but he needs all his efforts, all his influence, to bring the book and the reader together in his community. Sometimes by doing this he can be doing the other too, and he can always do it vicariously. He should 
bear in mind that the successful man is not he who does everything himself, but he who can induce others to do things-to do them in his way and to direct them toward his ends. Even in the most sluggish, the most indifferent community there are these potential workers with enthusiasms that need only to be awakened to be let loose for good. The magic key is often in the librarian's girdle, and his free offer of house room and sympathy, with good literature thrown in, will always be of powerful assistance in this kind of effort. He will seldom need to do more than to make clear the existence and the nature of the opportunity that he offers. I know that there are some librarians and many more teachers who hesitate to open their doors in any such way as this; who are afraid that the opportunities offered will be misused or that the activities so sheltered will be misjudged by the public. It has shocked some persons that a young people's dancing-class has been held, under irreproachable auspices, in one of our branch libraries; others have been grieved to see that political ward meetings have taken place in them, and that some rather radical political theories have been debated there. These persons forget that a library never takes sides. It places on its shelves books on the Civil War from the standpoint of both North and South, histories of the great religious controversies by both Catholics and Protestants, ideas and theories in science and philosophy from all sides and at all angles. It may give room at one time to a young people's dancing-class and at another to a meeting of persons who condemn dancing. Its walls may echo one day to the praises of our tariff system and on another to fierce denunciations of it.

These things are all legitimate and it is better that they should take place in a library or a school building than in a saloon or even in a grocery store. The influence of environment is gently pervasive. I may be wrong, but I cannot help thinking that it is easier to be a gentleman in a library, whether in social meeting or in political debate, than it is in some other places. In one of our branches there meets a club of men who would be termed anarchists by some people. The branch librarian assures me that the brand of anarchism that they profess has grown perceptibly milder since they have met in the library. It is getting to be literary, academic, philosophic. Nourished in a saloon, with a little injudicious repression, it might perhaps have borne fruit of bombs and dynamite.

In this catholicity I cannot help thinking that the library as an educational institution is a step ahead of the school. Most teachers would resent the imputation of partisanship on the part of the school, and yet it is surely partisan - in some ways rightly and inevitably so. One cannot well explain both sides of any question to a child of six and leave its decision to his judgment. This is obvious; and yet I cannot help thinking that there is one-sided teaching of children who are at least old enough to know that there is another side, and that the one-sided teaching of two-sided 
subjects might be postponed in some cases until two-sided information would be possible and proper. Where a child is taught one side and finds out later that there is another, his resentment is apt to be bitter; it spoils the educational effect of much that he was taught and injures the influence of the institution that taught him. My resentment is still strong against the teaching that hid from me the southern viewpoint concerning slavery and secession, the Catholic viewpoint of what we Protestants call the Reformation-dozens of things omitted from textbooks on dozens of subjects because they did not happen to meet the approval of the textbook compiler. I am no less an opponent of slavery-I am no less a Protestantbecause I know the other side, but I think I am a better man for knowing it, and I think it a thousand pities that there are thousands of our fellowcitizens, on all sides of all possible lines, from whom our educative processes have hid even the fact that there is another side. This question, as I have said, does not affect the library, and fortunately need not affect it. And as we are necessarily two-sided in our book material so we can open our doors to free social or neighborhood use without bothering our heads about whether the users are Catholics, Protestants, or Jews; Democrats, Republicans, or Socialists; Christian Scientists or suffragists. The library hands out suffrage and anti-suffrage literature to its users with the same smile, and if it hands the anti-suffrage books to the suffragist, and vice versa, both sides are certainly the better for it.

I have tried to make it clear in what I have said that in this matter of social activity, public institutions should go as far as they can in furnishing facilities without taking upon themselves the burden of administration. I believe fully in municipal ownership of all kinds of utilities, but rarely in municipal operation. Municipal ownership safeguards the city, and private or corporate operation avoids the numerous objections to close municipal control of detail. So the library authorities may retain sufficient control of these social activities by the power that they have of admitting them to the parts of the buildings provided for them, or of excluding them at any time. The activities themselves are better managed by voluntary bodies, and, as I have said, there is no indication that the formation of such bodies is on the wane. The establishment and operation of a musical or athletic club, a debating society, or a Boy Scouts company, are surely quite as educational as the activities themselves in which their members engage. Do not let us arrogate to ourselves such opportunities as these. I should be inclined to take this attitude also with regard to the public playgrounds, were they not somewhat without the province of this paper; and I take it very strongly with regard to the public school. Throw open the school buildings as soon as you can, and as freely as you can, to every legitimate form of social activity, but let your relationship to this activity be like that of the center to the circle-in it and of it, but embracing no part of its areal content. So, I am convinced, will it be best for all of us- 
for ourselves, the administrators of public property, and for the public, the owning body which is now demanding that it shall not be barred out by its servants from that property's freest and fullest use.

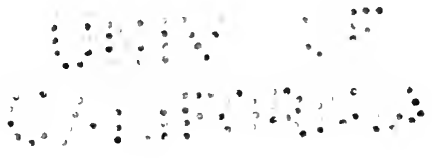





\section{DAY USE}

RETURN TO DESK FROM WHICH BORROWED

\section{LOAN DEPT.}

This book is due on the last date stamped below, date to which renewed. Renewals only:

or on the date Tel. No. 642-3405 Renewals may be made Renewed books are subject to 271

Due end of FALL Quarter HOV subiect to recall affer RERD LO OCT 2371 IOAT 7

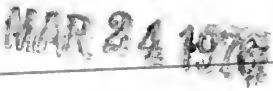

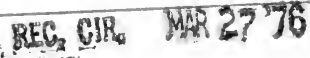

LD21A-40m-8,'71

(P6572s10) 476-A-32

General Library University of California Berkeley 
